DOI 10.18551/rjoas.2019-06.16

\title{
REVEALING THE ACCOUNTABILITY TRANSFORMATION OF COMMUNAL BASED MICROFINANCE INSTITUTIONS IN INDONESIA
}

\author{
Fauzi Nurul* \\ Accounting Department, Politeknik Negeri Padang \& Doctoral Program, \\ University of Brawijaya, Indonesia \\ Irianto Gugus, Hariadi Bambang, Roekhudin \\ Economic and Business Faculty, University of Brawijaya, Indonesia \\ *E-mail: nurfa2006@yahoo.co.id
}

\begin{abstract}
This research is aimed at revealing accountability practices at the oldest Communal Based Microfinance Institution in Indonesia, Lumbung Pitih Nagari. Lumbung Pitih Nagari is a traditional microfinance institution owned by the nagari community (traditional village) and transformed into a formal financial institution (rural credit banks and cooperatives). This research was carried out during 2017-2018 on several research sites spread across three districts / cities in Indonesia's West Sumatra province. Data collection is done by in-depth interviews, observation and documentation. Research informants were determined in advance for several key informants and the rest followed the snowball sampling pattern. Data analysis was carried out following 12 stages of sequential development methods introduced by Spradley in Realist ethnographic research. This study found a change in direction and form of accountability from the social base to rule base on the Lumbung pitih nagari which turned into rural credit bank. While the Lumbung pitih nagari turned into cooperatives, there was also a change in direction and form of accountability, although it was not significant, as happened in the Lumbung Pitih Nagari which turned into a rural credit bank. In the final section, this study found changes in the Lumbung Pitih Nagari to become a rural credit bank or cooperatives make the Lumbung Pitih Nagari uprooted from its roots as a communal nagari-based microfinance institution that should contribute to the development of economic, social, religious and cultural aspects of the Nagari community
\end{abstract}

\section{KEY WORDS}

Accountability, microfinance institutions, communal, ethnography, Lumbung Pitih Nagari.

The Province of West Sumatra Indonesia has a communal-based microfinance institution (MFi) that has been established long time ago. This microfinance institution is known as Lumbung Pitih Nagari (LPN). Base on Seibel (2001) and Chavez and Vega (1996) Lumbung Pitih Nagari was first established in the 1930s with the name Lumbung Padi Nagari (Communal rice store)(Fitri, 2006). This informal financial institution then developed into a semi formal financial institution owned by the nagari (traditional village) community after Indonesian independence in 1945 and reached its heyday in the 1980-1990 period. In its heyday, LPN was able to activate all aspects of the life of the Nagari society not only in economic aspects but also in social, cultural and religious aspects. LPN contributes in many ways besides providing credit for the Nagari community, but its also involved in the construction of the Nagari road, traditional Nagari events, mosque construction and others. (Holloh, 2001: Sila, 2010: Seibel \& Parhusip, 1998). Research conducted by Chavez and Vega (1996) even found Lumbung Pitih Nagari was one of eight models of rural microfinance institutions that were successful in Indonesia in the 1990s.

The success story of the LPN did not last long, starting from the issuance of government policies through the decision of the finance minister No. 1064 / KMK.00 / 1988 in October 1988 known as Pakto 88, then accompanied by the issuance of Law No. 7 of 1992 and Law No. 10 in 1998 which stated that the existing LPN had to change its legal entity to 
become a rural credit bank/Bank Perkreditan Rakyat (BPR) or cooperative. If this is not done, the existing LPN is no longer allowed to raise funds from the community. The Pakto 88 policy and this law were initially welcomed enthusiastically by the existing LPN managers, as evidenced by their willingness to change their LPN legal entity into a BPR. A year after the policy came out at least 27 LPNs that had changed legal entities to become BPRs (Sila, 2010: Oman, 1995).

At the beginning of the change to BPR there was no significant change in the governance of the LPN, especially in accountability forms. In the early days of the change, the LPN managers who had turned into BPRs still agreed to provide revenue sharing of 20 percent of the profits to the nagari as well as before they changed to BPR as a form of accountability to the nagari. Many social, religious and community activities that have led to public costs are still supported wholeheartedly by BPR managers. Time goes along with the entry of new investors as a consequence of the need for additional capital required by the Financial Service Authority (OJK), the costs of which are public costs begin to be reduced. The manager's direction of accountability has also slowly changed from the previous one fully to the Nagari community through the provision of profit sharing of 20 percent of LPN profits and support for various activities and development of the Nagari, slowly shifting towards shareholders and policy makers. This form of accountability also slowly changed to adjust to the rules issued by OJK at that time.

Based on various definitions of accountability, in essence accountability is often indicated by the direction and form of accountability provided (Gray et al, 1996: Ihsan, 2003: Ebrahim, 2003). According to Dixon et al (2006) the typology of accountability in microfinance institutions can be divided into four types which are divided into vertical accountability and horizontal accountability with reference to the relationship pattern developed.

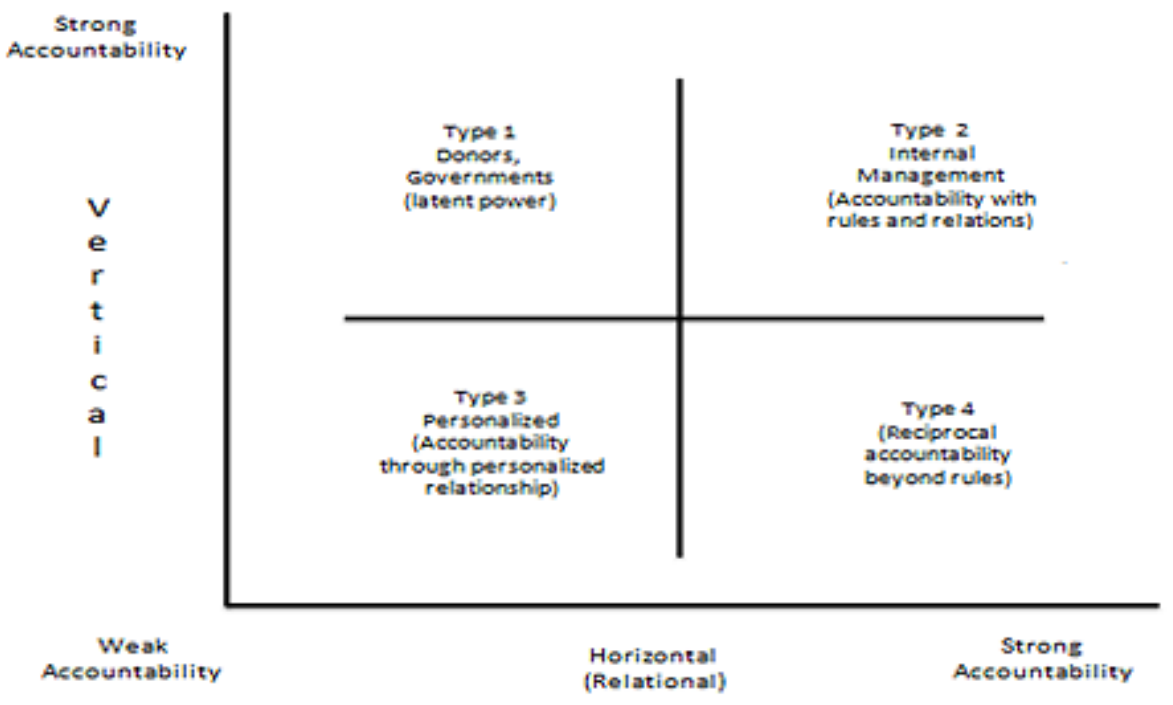

Figure 1 - Dixon's Accountability Framework

Type 1 accountability is upward-oriented vertical accountability, namely to donors and government. The relationship pattern developed by this type of microfinance institution is strong vertical relations to capital providers and the government. The main orientation is to meet the demands of donors and the government vertically such as preparing reports and meeting the rules requested by donors or government. This type considers MFIs to be more accountable when they are able to meet demands from above "Externally driven". This type has a pattern of weak relationships horizontally for example with the community or clients. Type 2 accountability is accountability that tries to combine a strong pattern of relationships vertically by preparing accountability reports as desired by the boss, the government and funders / financiers on the one hand while on the other hand they try to build stronger 
communication with clients in the community horizontally. Type 2 accountability is also called internal management accountability.

Accountability type 3 and type 4 should be the accountability needed by MFIs because, as revealed by Karim (1996), MFIs are basically designed to prioritize "relational accountability" rather than "rule base accountability". Accountability type 3 is accountability that is more concerned with relationships that strong with the community that was built personally by the loan officer (in the CETZAM case) discussed by Dixon et al. This type of accountability does not emphasize relations with donors or the government. While type 4 accountability is accountability that is in line with type 3 where vertical relations to donors and the government are not considered important but horizontal relations with clients are considered very important. Type 4 accountability requires a strong reciprocal relationship with the client beyond compliance with the rules.

Departing from the above problems, this research is intended to understand and to interpret the direction and form of accountability of the LPN that has changed it legal entity to BPR or cooperative at this time. This study tries to uncover the practice of accountability in the two types of microfinance institutions that were once communal-based microfinance institutions owned by the Nagari society.

\section{METHODS OF RESEARCH}

This study uses the interpretive paradigm because it aims to understand and interpret the practice of accountability in communal MFIs that have changed to BPR or cooperatives. The research method used is the method of realist ethnography (Creswell, 2013). Data collection was carried out through in-depth interviews, documentation and observations at four research sites spread across three districts / cities in West Sumatra, namely BPR LPN Pagaruyung, BPR Balerong Bunta, BPR Padang Magek and Pulau Mainan Cooperative. The informants interviewed were key informants who underwent a process of changing LPN accountability from social base to rule base. The selected informants came from the four research sites using the snowball sampling method. Data analysis was carried out using domain analysis, taxonomic analysis, componential analysis and others contained in twelve steps of the Spradley developmental research sequence methods (Spradley, 2006).

\section{RESULTS AND DISCUSSION}

Reality of Accountability in LPNs that Change to BPR. Referring to the initial purpose of establishing the Lumbung Pitih Nagari as stipulated in the regional regulation (Perda) No. 1 of 1982 it was stated that the LPN was established with the following objectives: a) encourage economic development of rural / urban / nagari people through directed savings and effective capital distribution b) Establish and collect capital for development in the village / nagari c) Realize a business of a social functioning savings and loan agency using Pancasila-based economic principles d) Create equity in business opportunities for residents and workers in rural or urban villages.

To make this purpose happen, LPN distributes capital loans for the Nagari community for economic empowerment and poverty alleviation and encourages various development activities oriented to the progress of the village. This means that in this condition the direction and form of accountability carried out by the LPN is correct in accordance with the initial purpose of establishing the LPN. The nagari community can feel the accountability given by the LPN to the nagari in the form of various development programs and activities such as the construction of village roads, the construction of mosques and worship facilities, the construction of ballrooms (traditional meeting places) and others. The community considers the accountability of the LPN to have been realized well through contributions to the Nagari development fund of twenty percent (20\%) of the portion of profits earned by LPN each year. With this condition the LPN manager feels that the full accountability that must be realized by the LPN manager is only for the nagari community, so that the identification of the main stakeholder needs only related to the needs of the nagari community. 
Today the conditions are different, refers to current practices of LPN that have changed to BPR, the direction and form of accountability that has been done has changed considerably. At present BPR are preoccupied with OJK provisions and regulations that they must fulfill as a consequence of being BPR. The orientation of the LPN manager is no longer the identification of the social base needs, but rather the fulfillment of the top down regulations issued by the Financial Services Authority (rule based). This can be captured from the excerpt interviews of BPR Pagaruyung Manager (Mr Dedet) and BPR Balerong Bunta Manager (Mr. Ekky) below:

"Especially now, OJK rules now, if capital (BPR) does not reach 3 billion in 2019 or 6 billion in 2024, then this BPR will be closed, or merged or turned into a cooperative" (excerpt interview with Mr Ekky).

"No more coaching is available, OJK is strict with its rules, for example like a mobile phone worth 1 million, of which 1 million is problematic, 1 million also loses BPR, if it used to be able to adjust. Now the rules for BPR are the same as commercial banks while the motion of commercial banks is limited. In a public bank there may be a lot of funds. Local governments can also enter there" (Excerpt interview with Mr Eki).

"If the OJK (a form of accountability) other than financial statements, of course the payment per quarter they request, is usually requested $0.03 \%$ of the assets per quarter. If it's calculated a year ago, we paid about 15 million (Excerpt interview with Mr Dedet).

"In the past when we didn't pay anything, we got coaching, now that we pay, the coaching is gone, all that is checking, investigating, closing. Paying us even the rules get worse ... hahaha" (excerpt of interview with Mr. Dedet).

From several excerpts from the interview above, it can be captured the current feeling of the BPR manager that reflects the changes in direction and form of accountability they are carrying out. Managers are preoccupied with fulfilling the latest regulations issued by the Financial Services Authority (OJK) such as changes in guarantee appraisal methods, the necessity of controlling shareholders, preparation of financial reports in accordance with Indonesian Financial Reporting Standart (SAK and SAK ETAP), and mandatory certification for commissioners and employees. The latest thing that has become a scourge for managers is the fulfillment of regulations related to capital adequacy of 3 billion in 2019 and 6 billion in 2024

For BPR managers, the fulfillment of capital adequacy impacts on many things, especially in dividend distribution. This is because the rules for fulfilling the 3 billion capital are followed by other provisions that stipulate that before the adequacy of the 3 billion capital is met, dividends may not be shared. This raises a separate problem for the managers of BPR as revealed by the results of an interview with the director and chief commissioner of BPR Pagaruyung following:

"As a result of this dividend it cannot be distributed, many investors are retreating, in West Sumatra people want to buy shares to get dividends, later if they get dividends payment, they can buy something. In our MFi because we are not being able to distribute dividends, my controlling shareholder (BPR) resigned. Every time I submit a capital increase to the shareholders of their weapons, we are reluctant to add capital, because dividends cannot be shared" (Excerpt interview with Mr. Dedet).

"...the issue of this dividend, If it may be distributed, of course the public trust will be even greater, the more willing they are to become investors in this BPR. In the past, while still allowed (shared), people were fighting over who wanted to invest, but after OJK rules like this, they became weak (slow) to fulfill this capital adequacy" (Excerpt interview with H Panji Commissioner BPR Pagaruyung).

This condition certainly creates a dilemma for managers and LPN owners who have changed to BPR. On the one hand, the manager is required to meet the capital adequacy of 3 billion rupiah in 2019 so that it can still operate as a BPR. To fulfill this obligation the most likely step taken by the managers is to increase capital from the shareholders, both the old shareholders and prospective new shareholders from outside. So far, to attract old shareholders to increase their share ownership or to attract prospective new shareholders to become shareholders in BPR is to promise attractive dividend distribution every year. For 
BPR Pagaruyung for example, so far the average shareholders receive dividends of not less than 25 percent of the capital they invest each year, so that in 4 years the shareholders have returned their full capital.

At present the dividend distribution is prohibited by the OJK before the 3 billion capital adequacy is fulfilled in 2019 so that many LPN managers have difficulties in fulfilling the capital adequacy of 3 billion in 2019. From the informal conversation with the managers of PT BPR, it was revealed that perhaps not more than 30 percent of the current BPR in West Sumatra province would be able to meet the 3 billion capital adequacy if the policy (related to dividends) was not changed.

The above is only one example of the problems faced by LPN managers who have changed to BPR. Of course, it can be imagined as an entity that has rule-oriented accountability, so the management days will only be busy with fulfilling the provisions and regulations so that the BPR operational license is not revoked. In psychological conditions like this, it is certain that there will be no longer found a form of community-based accountability (social base) which is actually the most appropriate form of accountability in community-based microfinance institutions such as LPN. At present there is no longer a contribution of 20 percent for nagari development funds or 5 percent for social funds as applied when the LPN has not changed to BPR. Even if there is a provision of social funds, the nature is only incidental depending on the proposal that goes to PT BPR LPN.

"...for us now, if there are proposals activities from Nagari, we certainly distinguish (with other proposals) because Nagari is part of the owner. Only for the village development fund (which is $20 \%$ ), we certainly cannot realize it, because there are no more rules, it is not allowed because we are already public. For example, if we do something like that in one village, other villages will also demand because now the shareholders are not (limited) only our nagari society again"(Excerpt interview with $\mathrm{H}$ Suhaili Director of BPR Padang Magek).

From the discussion above, it can be seen that the LPN that has changed to BPR has undergone a change in direction and form of accountability. If previously the accountability was aimed at the interests of the nagari community according to the focus of activities that will be carried out by the nagari, after becoming BPR, the LPN accountability direction of the LPN manager changed in the interests of shareholders and compliance with regulations stipulated by financial authorities in Indonesia (OJK).

The accountability of who (from who) also changes, if before becoming BPR responsibility as a form of accountability is carried out by the LPN management agreed upon by the members and decided by the Kerapatan Adat Nagari (KAN) then after becoming BPR responsibility is carried out by the BPR Commissioners and Directors appointed by shareholders through a general meeting of shareholders (GMS) held annually.

The form of accountability (information form) and the type of information (information needed) provided also changes along with the change in LPN to BPR. When it is in the form of LPN, the form of accountability is in the form of financial reports that are often not standardized with the type of information needed is information about development programs and economic empowerment and poverty alleviation programs that have been implemented for the Nagari community. After being a BPR information needed for accountability refer to circular of financial services authority (SEOJK) number 39 / SEOJK.032017 consisting of annual reports and publication reports.

Annual report contains a) general information covering management structure, ownership, BPR business development, management strategies and policies and management reports b) Annual financial statements for 1 (one) financial year consisting of balance sheets, income statement of the relevant financial year, report on changes in equity, cash flow statements and notes to financial statements c) Opinions from public accountants if the Annual Financial Report is audited by public accountants d) Disclosure of other information such as summaries of accounting policies, explanations of financial statement items, commitments and contingencies, developments the last is the financial accounting standard that applies to BPR, reclassification, the nature and impact of events and events after the balance sheet date and e) Management letter of the financial statement audit. While publication reports are BPR financial statements at the end of March, June, September and 
End of December which are a combination of the financial statements of the BPR head office and all of its branches.

Reality of Accountability on LPNs that Change to Cooperatives. Somewhat different from the LPN who changed its legal entity to BPR, the LPN that turned into a cooperative did not experience a change in direction and a form of significant accountability. From interviews that researchers have done with Mr. Ratno Sukoco the founder and manager of the cooperative LPN Pulau Mainan in Dhamasraya Regency, West Sumatra, it was revealed that before turning into a cooperative in Dhamasraya Regency itself there were 8 (eight) LPNs that survived as communal-based MFIs. Of the 8,3 have been changed to LPN Cooperatives, namely Pulau Mainan Cooperatives, Padang Bintungan Cooperative and Multi Usaha Sungai Rumbai Cooperative.

During the observations and interviews it was also revealed that in fact the image of the community towards the cooperative was not as good as the LPN, especially in Dhamasraya Regency because from several previous cases it was found that cooperatives were closed due to problems. Even if they can choose, the managers of the Pulau Mainan cooperative feel more comfortable in the form of LPN as before, as expressed by Mr. Ratno below:

"It is true, sir, if they could choose, they (the LPN cooperative managers) stated that they are still comfortable on the LPN, but because it is mandatory and at that time there is less guidance or protection. In 2014, we ourselves felt like that, sir, whose name holds a lot of money but the legality is not clear, sir" (Excerpt interview with Mr. Ratno).

From the interviews, it was also revealed that changes in the form and direction of accountability carried out by the managers of the LPN cooperative actually did not drastically change the direction and form of accountability carried out by the LPN managers who changed to PT BPR LPN.

"Actually, we didn't feel too much change (in accountability) just because we felt (needed) a legal umbrella yesterday that was fundamental" (Excerpt interview with Mr. Ratno).

This is caused by several things. 1) The LPN that turned into this cooperative without realizing it was actually in the form of cooperatives where capital originated from members through principal savings, mandatory savings and voluntary savings. 2) LPNs that turned into cooperatives on average were established LPN after the 2000 s long after the heyday of LPN passed and was not strongly tied to the regional regulations on LPN that had been applied before (Perda No. 1 of 1982) so that the governance and forms of accountability carried out also did not refer to these regulations.

For example, in terms of contributions to the nagari, if referring to the regulations mentioned above, of course the LPN must give contribution twenty percent of development funds and five percent of social funds from the profits of LPN every year. While the LPN-LPN established after 2000 this obligation is no longer carried out strictly as revealed from the following interview with Mr. Ratno.

"That is the nature of social fund, stated in the Statutes and bylaws of $5 \%$. Distribution is only based on the needs, on request. If we don't, we will make a allowance fund, sir, because all this time the village itself doesn't really care, so he also doesn't demand too much".

This condition is understandable because if in the 1970-1980 the establishment of the LPN was assisted by the provincial government in the form of capital grants / loans, while for LPN-LPN which was established after the 2000s the capital was purely from the founders who were also members of the LPN. Like the LPN Pulau Mainan at the time of establishment all of the capital Rp. 44,021,000 came from the founders of 35 people. There is no capital originating from government grants or equity participation from the Nagari.

It's mean that the direction (to whom) of the LPN before and after turning into a LPN cooperatives actually does not change drastically, only to the members of the cooperative, while the community is only in the form of social responsibility as stipulated in the Statutes and bylaws of each cooperative. In line with this, the party burdened with the responsibility to provide accountability (from who) also does not change drastically, it is still carried out by the 
LPN management or the LPN cooperative chosen and determined at the Annual Member Meeting.

Things that change are only forms of accountability (type of accountability) and types of information provided in providing responsibility. If before becoming a cooperative form of accountability is manifested in the form of self-designed financial statements based on the needs of LPN without certain rules governing, after becoming an LPN cooperative the form of accountability and type of information refers to the Minister of Cooperatives and Small and Medium Enterprises Regulation Number 13 /Per/M.KUKM/IX/2015 concerning guidelines for Accounting for Savings and Loans by Cooperatives. In this regulation, the form of accountability of savings and loan cooperatives is regulated through financial statements of savings and loans cooperatives which consist of 1) Balance Sheet, 2) Report on calculation of business results, 3) Reports on changes in equity, 4) Cash flow reports and 5) Notes to financial statements.

Here it can be concluded that there was no significant change from the direction and form of LPN accountability before or after changing into LPN cooperatives not because of the conformity between LPN and LPN cooperatives, but because the LPN-LPN established after the 2000s had indeed shifted from the initial form of LPN as stipulated in Perda No. 1 of 1982.

This mismatch has begun from the different objectives of establishing the LPN. If referring to Perda No. 1 of 1982 expressly stated the purpose of establishing the LPN is to encourage economic development of the village/nagari and create a business of a savings and loan agency that has social functions and is not limited to economic functions. While the LPN which was established after the 2000s and later turned into a cooperative focused more on economic goals, namely to improve the welfare of members who met in LPN cooperatives without explicitly including other social functions carried out as revealed by Mr. Ratno below:

"The purpose of establishing LPN for those of us who were 35 people initially was only to improve the economy of members, from the beginning the form of this LPN was cooperative form, there were basic savings, mandatory etc. We will set aside some of the results for the Nagari".

Reflection of Result. If using the accountability framework suggested by Dixon above, Type 1 accountability is accountability that is currently applied by the LPN that changes to BPR LPN and leaves its initial form as a community-based MFI. This is illustrated by the manager's current orientation, namely vertically trying to fulfill the rules issued by the government through the OJK and efforts to get the maximum profit to maximize the welfare of the shareholders.

Discussions among BPR managers during field observations were only related to the fulfillment of OJK obligations such as capital adequacy of 3 billion rupiah in 2019 and 6 billion rupiah in 2024, fulfillment of collateral aspects, efforts to meet financial disclosure and reporting standards and others. No discussion at all was oriented towards fulfilling horizontal accountability to the community such as the construction of nagari, support for traditional activities in the nagari and activities that encourage the progress of the nagari. Even if there are funds or donations given to the community, they are more voluntary and incidental when there are proposals for community activities.

This is certainly very different from the LPN before it experienced changes in objectives and mission. In the past LPN had the main goal of encouraging the development of the nagari, helping social activities, religion and culture of the community so that the nagari community felt they had an LPN. Now the conditions are different, whether or not BPR in one nagari makes any difference to them. This is further emphasized by the loss of LPN profit sharing contributions of twenty percent of profits for the nagari which were previously always given.

In addition, there is also a change in the managerial paradigm where after changing to BPR, helping social activities, religion and cultural customs in the nagari where LPN is located is no longer considered an obligation of the LPN. LPN managers maintain vertical relations with shareholders and the government in this case more than maintaining horizontal relations with the Nagari community where the LPN operates. 
For LPNs that turn into cooperatives, accountability type 4 may be closer to their current conditions where mutual relations between cooperative managers and clients in this case cooperative members are strongly interwoven. Cooperative managers feel horizontally responsible for meeting members' needs through providing loans with low interest rates and the process is not difficult. In LPN cooperatives loans can also be "customized" according to the needs of members, although for these conditions it is often discussed first in the annual member meeting.

A strong horizontal relation between the cooperative managers and members of the LPN cooperative is the key to the success of the LPN cooperative's accountability. For LPN cooperative managers the relationship vertically to fulfill the wishes of capital owners is not too important because the owners of capital are themselves, while vertical relations to the government are not too urgent because so far the cooperative service is more coaching and does not provide pressure like the OJK culminating in sanctions if not followed.

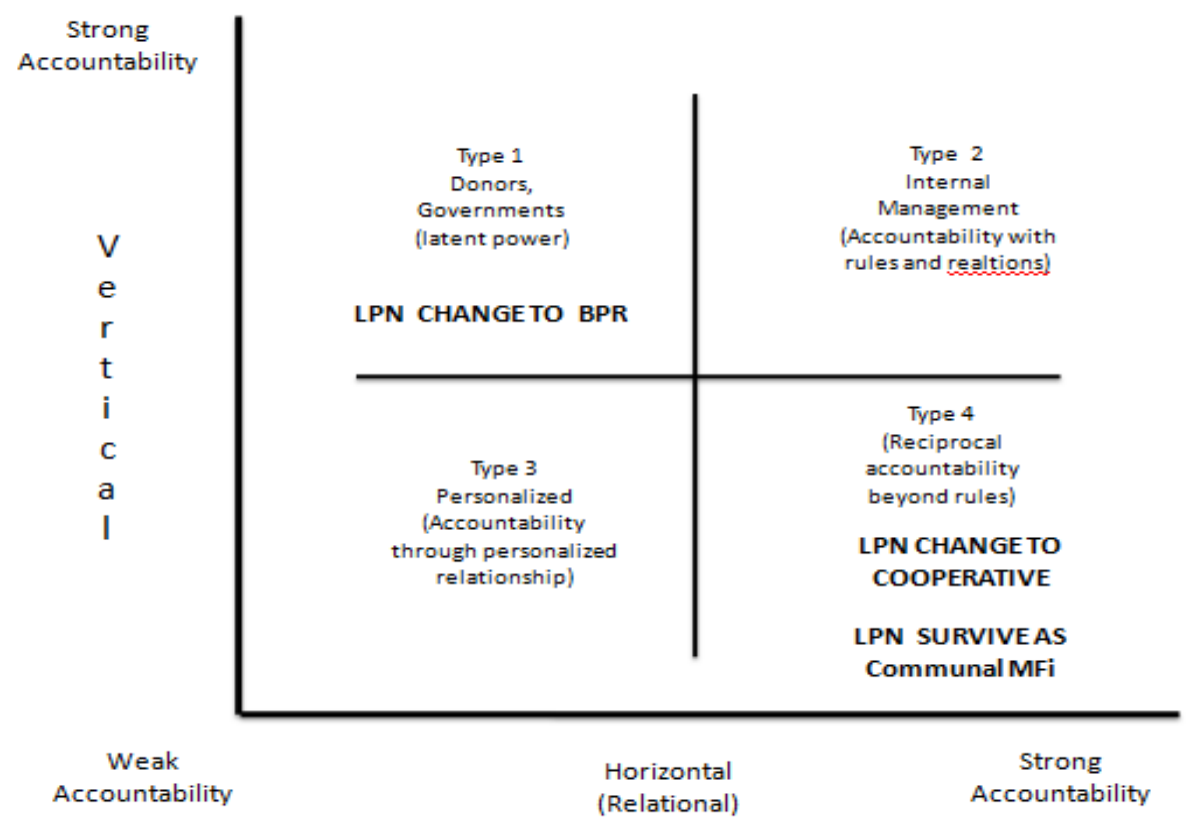

Figure 2 - Accountability of LPN in the Dixon Framework

Similar to the LPN which turned into a cooperative, on LPNs that still survive as communal-based MFIs, Type 4 of accountability more appropriate to describe their current conditions. Now LPNs that still survive as communal-based MFIs such as LPN Limau Manis do not feel they have a vertical accountability relationship to both the fund owners and the government in this case the OJK as the authority holder. The OJK staff themselves when asked by researchers about the status of LPN still survive as communal based MFi in West Sumatra stated that the LPN was beyond their supervision. This is reinforced by the existence of Law No. 1 of 2013 concerning microfinance institutions which states that LPN, LPD and other similar institutions that have existed before this Act was issued have the right to self-management without having to be bound by government regulations. LPN managers also feel that they are not required to provide annual reports and other reports that are needed just like other microfinance institutions.

While horizontally to the community they feel they must have strong relational relationships. Their main responsibility is to the community through the programs they roll out for the interests of the nagari. Somewhat different from Dixon et al's proposed accountability framework for the case of the MFIs they studied (CETZAM) where accountability was built through "personalized relationships" with clients, then on communal-based LPN the pattern of relations with the community must be built through reciprocal programs explained and directed according to the needs of the nagari, so that the pattern of horizontal relations shifts 
to the right (strong), From this it can be concluded that the more appropriate form of accountability to describe the LPN that still survives in communal form is in type 4.

\section{CONCLUSION}

Based on the discussion above, it can be concluded that there is evidence that shows a significant change in accountability on the LPN that turns into BPR from social base to rule based. If before changing to a BPR, the accountability of the LPN is directed horizontally to the Nagari community through nagari programs and the contribution of 20 percent of the profit for the development of the nagari but after changing to BPR the direction of accountability changes which are vertically addressed to shareholders and government official OJK.

The form of accountability also changes, if before becoming a BPR, LPN forms accountability in the form of nonstandard LPN financial statements (containing financial information with emphasis on programs for nagari), then after becoming a BPR forms accountability refers to SEOJK number 39 / SEOJK.032017 which consists of annual reports and publication reports. In addition, those who gave accountability also changed from the LPN management to the board of directors of the LPN through the general meeting of shareholders.

On LPN that changed into cooperative the direction of accountability did not undergo drastic changes. Before has a legal entities, the direction of LPN accountability was also directed at the members of the cooperative, not entirely to the Nagari community. This is because most LPNs that turn into LPN cooperatives are LPNs that were born after 2000 and have not felt tied to the regulation No. 1 of 1982 governing LPN. After becoming an cooperative and the entry of new members from outside (nagari) the direction of cooperative accountability was increasingly member oriented, which led to the loss of contributions to nagari.

Although there was no significant change in the direction of LPN cooperative accountability, the form of accountability experienced a significant change, if before becoming a cooperative LPN the form of accountability was almost the same as the other LPN, namely in the form of nonstandard financial reports prepared according to cooperative needs but after becoming LPN cooperatives the form of accountability refers to the Minister of Cooperatives and Small and Medium Enterprises Regulation of the Republic of Indonesia Number 13 / Per / M.KUKM / IX / 2015 concerning the Guidelines for Accounting for Savings and Loans by Cooperatives.

As a conclusion, in line with Sila (2010) study, the change in LPN to become a BPR or a cooperative made LPN be rooted from its roots as a communal-based microfinance institution whose direction and form of accountability should be aimed entirely at developing social, cultural and religious aspects of the community (social base) not intended for shareholders or policy makers (rule base)

\section{REFERENCES}

1. Chavez Rodrigo A \& Vega Claudio G. 1996: The Design of Succesfull rural Financial Intermediaries: Evidence from Indonesia: World Development, Vol 24, issue 1, https://doi.org/10.1016/0305-750X(95)00114-R.

2. Creswell, John W., 2013. Qualitative Inquiry \& Research Design, Choosing Among Five Approch ,(California: Sage Publications, 2013).

3. Dixon, R., Ritchie, J. \& Siwale, J., 2006. Microfinance: accountability from the grassroots. Available at: http://dx.doi.org/10.1108/09513570610670352.

4. Ebrahim, A., 2003. Accountability In Practice: Mechanisms for NGOs. World Development, Vol 31(5), pp.813-829.

5. Fitri, R., 2006. Informal Finance and Poverty Alleviation: A Grassroots Study of Small farmers' Credit In West Sumatera, Indonesia, Unpublished Disertation Massey University, New Zealand. 
6. Gray, R., Owen, D., \& Adams, C. (1996). Accounting and accountability, changes and challenges in corporate social and environmental reporting. Prentice Hall Europe.

7. Holloh, D., 2001. ProFI Microfinance Institutions Study. Denpasar.MoF BI GTZ-ProFi.

8. Insan Hidayatul, 2013. Understanding Accountability in A Waqf Institution: The Case of Dompet Dhuafa. International Islamic University Malaysia.

9. Karim, M. (1996), "NGOs in Bangladesh: issues of legitimacy and accountability", in Edwards, M. and Hulme, D. (Eds), Beyond the Magic Bullet: NGO Performance and Accountability in the Post Cold War World, Earthscan, London.

10. Oman, Endang. 1995, Analisis Keragaan dan Faktor Berpengaruh Terhadap Pengembalian Kredit; Kasus Lumbung Pitih Nagari Sumatera Barat, Skripsi Fakultas Pertanian Institut Pertanian Bogor.

11. Peraturan Daerah Gubernur Sumatera Barat No 1 tahun 1982 Tentang Lumbung Pitih Nagari.

12. Seibel, H.D., 2001. Rural finance: Mainstreaming informal financial institutions. Journal Development. Entrepreneurship. 6, 83.

13. Seibel, H.D., Parhusip, U., 1998. Microfinance in Indonesia An Assessment of Microfinance Institutions Banking with the Poor. Economic. Sociologi. Occas. Paper. 2365.

14. Sila, M.A., 2010. Lembaga Keuangan Mikro dan Pengentasan Kemiskinan : Kasus. jurnal sosiologi Masyarakat, 15(1), pp.1-19.

15. Spradley, James P. 2006. Metode Etnografi. Edisi kedua, Yogyakarta: Tiara Wacana Yogya.

16. Undang-Undang No 7 Tahun 1992 Tentang Perbankan, Dewan Perwakilan Rakyat Republik Indonesia.

17. Undang-Undang No 10 tahun 1998 Tentang Perubahan atas UU No 7 Tahun 1992 Tentang Perbankan, Dewan Perwakilan Rakyat Republik Indonesia.

18. Undang Undang No 1 Tahun 2013 Tentang Lembaga Keuangan Mikro. Dewan Perwakilan Rakyat Republik Indonesia. 